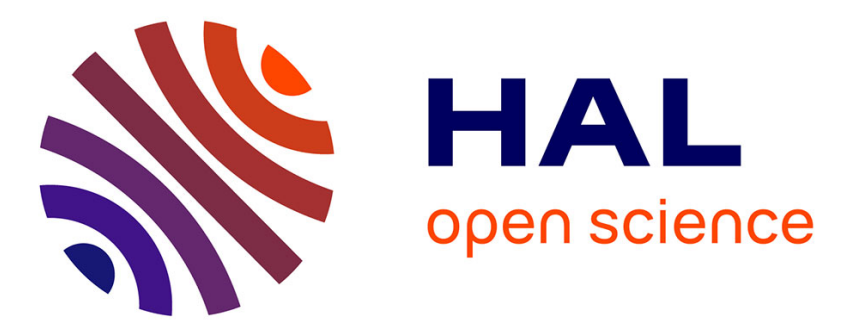

\title{
Synchronous barium peaks in high-resolution profiles of calcite and aragonite marine bivalve shells
}

David Paul Gillikin, Anne Lorrain, Yves-Marie Paulet, Luc André, F. Dehairs

\section{To cite this version:}

David Paul Gillikin, Anne Lorrain, Yves-Marie Paulet, Luc André, F. Dehairs. Synchronous barium peaks in high-resolution profiles of calcite and aragonite marine bivalve shells. Geo-Marine Letters, 2008, 28 (5-6), pp.351-358. hal-00452787

\section{HAL Id: hal-00452787 \\ https://hal.science/hal-00452787}

Submitted on 3 Feb 2010

HAL is a multi-disciplinary open access archive for the deposit and dissemination of scientific research documents, whether they are published or not. The documents may come from teaching and research institutions in France or abroad, or from public or private research centers.
L'archive ouverte pluridisciplinaire $\mathbf{H A L}$, est destinée au dépôt et à la diffusion de documents scientifiques de niveau recherche, publiés ou non, émanant des établissements d'enseignement et de recherche français ou étrangers, des laboratoires publics ou privés. 


\section{Synchronous barium peaks in high-resolution profiles of calcite and aragonite marine bivalve shells}

David Paul Gillikin ${ }^{1,2}$, Anne Lorrain ${ }^{3}$, Yves-Marie Paulet ${ }^{4}$, Luc André $^{5}$, \& Frank Dehairs ${ }^{2}$

${ }^{1}$ Dept. of Earth Science and Geography, Vassar College, 124 Raymond Avenue, Poughkeepsie, NY 12604,

USA. Tel.: (845) 437-7138; fax: (845) 437-7577; E-mail: dagillikin@vassar.edu; ${ }^{*}$ Corresponding author.

${ }^{2}$ Department of Analytical and Environmental Chemistry, Vrije Universiteit Brussel, Pleinlaan 2, 1050 Brussels, Belgium.

${ }^{3}$ IRD, US CHRONOS, LASAA, Centre IRD de Brest, BP 70, 29280 Plouzané, France.

${ }^{4}$ LEMAR, UMR CNRS/UBO 6539, IUEM, Place Nicolas Copernic, 29280 Plouzané, France.

${ }^{5}$ Section of Mineralogy and Petrography, Royal Museum for Central Africa, Leuvensesteenweg 13, B-3080 Tervuren, Belgium.

Accepted: special issue in Geo-Marine Letters 


\begin{abstract}
Barium/Calcium profiles of bivalve shells are characterized by flat background signals periodically interrupted with sharp peaks, with the background signals correlated with water $\mathrm{Ba} / \mathrm{Ca}$. To test if the peaks are an environmental signal related to productivity, we analyzed high resolution $\mathrm{Ba} / \mathrm{Ca}$ profiles in bivalve shells that grew adjacent to one another. Two aragonitic Saxidomus giganteus show remarkable similarity over a decade of growth, clearly indicating an environmental forcing. Four calcitic Pecten maximus shells also record synchronous $\mathrm{Ba} / \mathrm{Ca}$ peaks, again indicating an exogenous control. The $\mathrm{Ba} / \mathrm{Ca}$ peaks, however, start $\sim 40$ days after the crash of the bloom, while sedimentation takes place immediately following the bloom. Barite formation in settling phytoplankton flocs, as has been previously proposed, is clearly not the cause of these peaks. Other possible causes such as dissolved Ba in ambient water, spawning, shell organic matter content and kinetic growth rate effects are also discussed, but none provide satisfactory explanations. Background shell Ba partition coefficients $\left(\mathrm{Ba} / \mathrm{Ca}_{\text {carbonate }} / \mathrm{Ba} / \mathrm{Ca}_{\text {water }}\right)$ for both the calcitic shells (0.18) and aragonitic shells (0.16) are similar to that previously reported for the calcitic Mytilus edulis ( 0.1). We suggest that $\mathrm{Ba} / \mathrm{Ca}$ peaks in bivalve shells are caused by an as of yet undetermined environmental forcing, while background $\mathrm{Ba} / \mathrm{Ca}$ levels are a good indication of dissolved $\mathrm{Ba} / \mathrm{Ca}$ in the water; both are independent of shell mineralogy.
\end{abstract}




\section{Introduction}

Elemental signatures in biogenic carbonates such as corals and foraminifera are well known proxies of climate change and past environmental conditions (see Lea, 2003 for review). However, elemental signatures in bivalve shells are generally not well correlated with environmental conditions due to strong vital effects (e.g., Purton et al., 1999; Takesue and van Geen, 2004; Freitas et al., 2006; Gillikin et al., 2005a; Lorrain et al., 2005; Carré et al., 2006; Surge and Walker, 2006). On the other hand, $\mathrm{Ba} / \mathrm{Ca}$ ratios do seem to have potential as an environmental proxy. There is a nearly ubiquitous $\mathrm{Ba} / \mathrm{Ca}$ signal in all bivalve shells: a more or less constant $\mathrm{Ba} / \mathrm{Ca}$ background that is interrupted with sharp episodic peaks (Stecher et al., 1996; Vander Putten et al., 2000; Lazareth et al., 2003; Carré et al. 2006; Gillikin et al., 2006). The $\mathrm{Ba} / \mathrm{Ca}_{\text {background }}$ has been shown to be a reliable proxy of $\mathrm{Ba} / \mathrm{Ca}_{\text {water }}$ in Mytilus edulis (Gillikin et al., 2006) and the sharp peaks seem to be reproducible between different shells growing in the same location indicating an environmental forcing (Vander Putten et al., 2000; Carré et al., 2006). Stecher et al. (1996) first noted these peaks in the aragonite shells of two marine clam species. They postulated that these peaks may represent periods of barite $\left(\mathrm{BaSO}_{4}\right)$ formation immediately following phytoplankton blooms. Barite is believed to form in organic-rich decaying phytoplankton flocs, where $\mathrm{BaSO}_{4}$ saturation conditions might prevail (Dehairs et al., 1980; Bishop, 1988). Vander Putten et al. (2000) suggested that the $\mathrm{Ba} / \mathrm{Ca}$ peaks in calcite mussel shells provide excellent markers for spring phytoplankton blooms, but noted there was no direct relationship between peak height and chlorophyll $a(\mathrm{Chl} a)$ concentrations. Lazareth et al. (2003) also postulated that the $\mathrm{Ba} / \mathrm{Ca}$ peaks in a tropical calcitic bivalve were related to phytoplankton blooms. Other potential causes of these peaks could be short increases of dissolved $\mathrm{Ba}$, biological partitioning of $\mathrm{Ba}$ to calcification sites (such as during spawning), or differences in shell micro-structure (see Gillikin et al., 2006 for review). In bivalves, these peaks are not generally considered to be correlated with riverine discharge (see discussion), as they can be with in corals (e.g., McCulloch et al., 2003; Sinclair and McCulloch, 2004).

The aim of this study is to compare $\mathrm{Ba} / \mathrm{Ca}$ profiles between shells grown at the same location and then to compare shell data with environmental parameters. We also look at 
shell background $\mathrm{Ba} / \mathrm{Ca}$ data from these species to determine if they are potentially a proxy of water $\mathrm{Ba} / \mathrm{Ca}$ as Gillikin et al. (2006) proposed for Mytilus edulis. In order to determine if these $\mathrm{Ba} / \mathrm{Ca}$ peaks are reproducible between specimens growing in the same locality, which would suggest an extrinsic cause, we sampled two aragonitic Saxidomus giganteus shells from Puget Sound (Washington, USA) which provided a 10 year $\mathrm{Ba} / \mathrm{Ca}$ record and four calcitic Pecten maximus shells from the Bay of Brest (France) that provide precisely time resolved $\mathrm{Ba} / \mathrm{Ca}$ profiles. Several environmental parameters recorded during shell growth were also available from these sites such as temperature, salinity and $\mathrm{Chl} a$ concentrations.

\section{Materials \& Methods}

We chose Saxidomus giganteus (Fig. 1a) and Pecten maximus (Fig 1b) for analysis for several reasons. Saxidomus giganteus provides 1) a long term record ( 10 years) from a single shell allowing ontogenic effects on peaks and background $\mathrm{Ba} / \mathrm{Ca}$ ratios to be determined and 2) is an example of an aragonitic bivalve. The calcitic Pecten maximus, although only providing a short record $(<1 \mathrm{yr})$, allows precise matching between shell and environmental variables. Shells of both of these species have been studied extensively (e.g., Chauvaud et al. 1998, 2005; Lorrain et al., 2000, 2005; De Ridder et al., 2004; Gillikin et al., 2005a, b; Gillikin 2005; Freitas et al., 2006; Kingston et al., 2008).

The two S. giganteus shells were collected from intertidal sediments of Puget Sound (Washington, USA), and have been described in detail elsewhere (Gillikin et al., 2005a, b). Shells were sampled in cross-section along the axis of maximum growth, thus providing a high-resolution elemental profile spanning $\sim 10$ years. To compare data between shells and environment, the $\delta^{18} \mathrm{O}$ profiles were used (presented in Gillikin et al., $2005 \mathrm{~b}$ ). Briefly, the $\delta^{18} \mathrm{O}$ signal was fit between the two shells ( $\mathrm{x}$-axis of one shell scaled to the other). Then the $\delta^{18} \mathrm{O}$ signal was converted to a temperature (SST) signature using a constant $\delta^{18} \mathrm{O}_{\text {water }}$ and the paleotemperature equation of Böhm et al. (2000). This modeled temperature was then fit to environmental SST (scaling the $\mathrm{x}$-axis only) using the algorithm described in De Ridder et al. (2004) (see Gillikin et al. (2005b) for 
complete details; this resulted in a correlation coefficient $\left(\mathrm{R}^{2}\right)$ of $\left.\sim 0.8\right)$. Considering we did not account for variability in water $\delta^{18} \mathrm{O}$, this is a fairly good correlation, but nevertheless does lead to an unknown error in determining the exact timing of the samples taken from the shell. Shell $\mathrm{Ba} / \mathrm{Ca}$ ratios were determined using laser-ablation ICP-MS (Fisons-VG frequency quadrupled Nd-YAG laser $(266 \mathrm{~nm}$ ) coupled to a FisonsVG PlasmaQuad II+ ICP-MS) as described in Gillikin et al. (2005a) and (2006). Data from LA-ICP-MS were calibrated using both the NIST 610 (values from Pearce et al. (1997)) and the USGS MACS1 (values from S. Wilson, USGS, unpublished data, 2004). The laser was shot directly in the drill holes used to generate the $\delta^{18} \mathrm{O}$ data allowing a precise alignment between the two methods (see Gillikin et al., (2005a) and (2006)). Environmental SST and Chl $a$ data are from the Washington State Department of Ecology (http://www.ecy.wa.gov/).

The P. maximus shells (three age class I, with one winter growth check, and one age class II, with two winter growth checks) were collected from $30 \mathrm{~m}$ depth in the Bay of Brest (France) in 2003; the age class I shells are the same shells presented in Lorrain et al. (2005). Daily growth rate was determined by measuring distances between successive daily growth striae (external growth increments; Fig 1c) as described in Chauvaud et al. (1998). The method used to assign a precise date to each increment has already been well developed in several papers (e.g., Lorrain et al., 2004; Chauvaud et al. 2005). Each year, the date of growth restart is calculated by counting and measuring the daily increments from the edge of the shell to the first winter mark on 50 juveniles from the same cohort sampled at different moments during the growth season. Dates are thus assigned by backdating from the collection date. A mean profile is obtained by minimizing the sum of the differences between the different growth profiles (Walter and Pronzato, 1994). This mean curve is then used as a reference to assign dates to the striae from any new specimen. A potential error can come from the fact that some individuals may experience a short growth hiatus of a couple of days as a result of a disturbance. An additional source of error may be that a few striae can be broken from manipulation at the ventral edge of the scallop. The error is on the magnitude of a few days; from approximately 1 to 7 days depending on the scallop. The excellent correlation $\left(\mathrm{R}^{2}=0.92\right)$ found between $\delta^{18} \mathrm{O}$ and 
temperature in P. maximus from this same location (Chauvaud et al., 2005) confirms that the backdating is in fact very precise. Furthermore, a maximum error of one week would in fact not change any of our interpretations.

Carbonate powders representing $\sim 1-6$ days growth (covering the 2003 growth season) were milled from the P. maximus shells and were acid digested before being analyzed on an HR-ICP-MS (Finnigan Element2) as described in Lorrain et al. (2005).

Reproducibility of an in-house calcite bivalve shell reference material was $6.4 \%(\mathrm{Ba} / \mathrm{Ca}=$ $\left.1.21 \pm 0.08 \mu \mathrm{mol} \mathrm{mol}^{-1}\right)$. Water was continuously monitored over the lifetime of the scallops for SST and Chl $a$ (fluorescence) with a Sea-bird 19 sonde. In the same location and year, reproductive activity of three-year old scallops was assessed by fortnightly sampling of twenty individuals. Three-year-old individuals were used because their larger gonads allow more precise sampling; however, previous studies show high reproductive synchronism between age group in this species (Paulet and Fifas, 1989). For each date, a gonad index was calculated as the dry weight of the gonad divided by the shell weight and multiplied by 1000 (see Paulet et al., 1992 for details).

\section{Results \& Discussion}

\section{$\mathrm{Ba} / \mathrm{Ca}$ Peaks}

The inter-individual synchronicity of peaks in the shells of the two species is clearly evident in Figures 2 - 4. The very large, sharp peaks in 1993 (2 peaks), 1994 and 1999 are timed exactly in both S. giganteus shells (red arrows, Fig. 2; Fig 3a). Ba/Ca was independently fit using $\delta^{18} \mathrm{O}$ cycles (Gillikin et al., 2005b), so the exact peak match is strong evidence of a good time base reconstruction. However, the offset in the 1996 peaks (red circle, Fig. 2; Fig 3b) could be due to improper $\delta^{18} \mathrm{O}$ alignment between the two shells, as this was the most difficult section of the shells to date (see Gillikin et al., 2005b). This offset approximates 80 days, which is considered the maximum error on the fit between shells. However, it should be kept in mind that the other regions of the shell seem to be fit more precisely (e.g., Fig $3 \mathrm{a})$. The smaller peaks $(<10 \mu \mathrm{mol} / \mathrm{mol})$ are generally more variable in shape, but still seem to be somewhat reproducible between shells. For the more precisely timed P. maximus data, the apexes of the large peaks all 
fall within seven days of each other (this is a combined error of backdating striae and time averaging several striae in each carbonate sample milled from the shell) (Fig. 4). Nevertheless, the reproducibility between the shells strongly suggests that these peaks are a response to an exogenous factor in both species, or, if not, the result of a very well timed endogenous process.

There are several possible hypotheses that can be put forward regarding the cause of these $\mathrm{Ba} / \mathrm{Ca}$ peaks. The link with primary production mentioned in the introduction, variations in dissolved $\mathrm{Ba} / \mathrm{Ca}$ in the water in which the bivalve is growing, variability in shell organic matter content, kinetic growth rate effects, and the consequence of a precisely timed and synchronous physiological process such as spawning are all plausible hypotheses. With the evidence at hand, we will discuss each of these possibilities.

In corals, $\mathrm{Ba} / \mathrm{Ca}$ peaks have been shown to coincide with flood plumes which bring lower salinities and higher dissolved barium to the coastal zone (McCulloch et al., 2003; Sinclair et al., 2004). There is generally a linear inverse relationship between salinity and dissolved barium concentrations (Coffey et al., 1997; Sinclair et al., 2004; Gillikin et al., 2006). Variability in dissolved barium concentrations as a source for the $\mathrm{Ba} / \mathrm{Ca}$ peaks in P. maximus is highly unlikely, as the Bay of Brest is a rather stable environment with marine salinities year-round (Chauvaud et al., 2005). Additionally, if the background and peak incorporation mechanism were the same, the $\mathrm{Ba} / \mathrm{Ca}$ ratio of the water would need to increase 5 to 10 times, which is highly improbable considering salinity only varies a few units over the year (Lorrain et al., 2005). Salinity slowly increases from 33.1 to 35.6 from March to September and can therefore not explain the $\mathrm{Ba} / \mathrm{Ca}$ peaks measured in the shells (salinity mimics the temperature profile shown in Fig. 4; see Fig. 2 in Lorrain et al., 2005).

In bivalve shells, the $\mathrm{Ba} / \mathrm{Ca}$ peaks are generally believed to be related to primary productivity (Stecher et al., 1996; Vander Putten et al., 2000; Lazereth et al., 2003). Phytoplankton decay, sedimentation, and release of barium should happen quickly after a bloom in an estuary ends (Stecher and Kogut, 1999; Ganeshram et al., 2003). Most of the 
barium released after a bloom is labile and only a minor fraction forms barite crystals (Ganeshram et al., 2003). Therefore, if labile barium, either in phytoplankton or released into the dissolve phase, was the cause of the $\mathrm{Ba} / \mathrm{Ca}$ peaks, these peaks should form near the end of the bloom or very shortly thereafter. The $\mathrm{Ba} / \mathrm{Ca}$ peaks are not systematically occurring near the end of the Chl $a$ peaks in S. giganteus shells; however, due to possible errors in aligning the shell and environmental data we cannot conclude a lack of correlation. Nevertheless, it is clear that $\mathrm{Chl} a$ amplitude is not related to $\mathrm{Ba} / \mathrm{Ca}$ peak amplitude (also noted by Vander Putten et al. (2000) in Mytilus edulis); despite the large Chl $a$ peaks in 1997, 1998 and 2000, there are only minor Ba/Ca peaks during these years (Fig 2). Considering the errors associated with the fit between shell and environmental data, we rely more heavily on the $P$. maximus shells which are much more precisely timed.

The four P. maximus shells also show a high correlation between Ba/Ca peaks (Fig. 4). All shells exhibit a double peak, with the first large peak and second smaller peak synchronizing between all shells including both age classes, which illustrates that there is no ontogenic effect on these $\mathrm{Ba} / \mathrm{Ca}$ profiles in $P$. maximus. There is a remarkable similarity in the $\mathrm{Chl} a$ and $\mathrm{Ba} / \mathrm{Ca}$ peak shapes (i.e, the presence of a large peak followed by a smaller peak), however, they are offset by about 40 days. The phytoplankton bloom crashed on the $12^{\text {th }}$ of May, while the $\mathrm{Ba} / \mathrm{Ca}$ peak started about the $21^{\text {st }}$ of June. Moreover, the sedimentation of phytoplankton occurs around the end of the bloom as is evidenced by a sharp reduction in growth rate (Fig. 5). This phenomenon has been previously described in Chauvaud et al. (1998) and in Lorrain et al. (2000); briefly, the growth reduction is caused by the sedimentation clogging the gills of the scallops and/or a reduction in oxygen at the water-sediment interface as a result of the decaying phytoplankton. Barite formation in settling phytoplankton flocs, or the Ba-rich phytoplankton itself, is clearly not the cause of these peaks, since the growth reduction and $\mathrm{Ba} / \mathrm{Ca}$ peaks should then have coincided, which is not observed (Figs. 4 and 5). However, Ganeshram et al. (2003) found that barite formation can take several weeks to reach its maximum after the decay of phytoplankton starts. Perhaps barite is formed at the sediment surface and is ingested by the scallops several weeks after the phytoplankton 
bloom ends. Although only a small amount of barium is converted to barite, the barite could provide a high concentration of $\mathrm{Ba}$ if it dissociates in the gut of the bivalve. It is convenient to suggest that there is indeed a link between phytoplankton and $\mathrm{Ba} / \mathrm{Ca}$ peaks due to the synchronicity of the S. giganteus $\mathrm{Ba} / \mathrm{Ca}$ profile and the similarity in the peak shapes in P. maximus. However, it would be surprising that the double peak is persevered in P. maximus. If there was a biological filtering or delay in barite formation in the sediments, the signal in the shell would most likely be averaged and would not show the discreet double peak. Detailed time-resolved experiments are needed to determine if this is the case. If barite is the cause, it should be visible in the gut of bivalves at the time of $\mathrm{Ba} / \mathrm{Ca}$ peak formation. Experiments over several years following the complete Ba cycle in the water and in the bivalve (e.g., different tissues, gut and shell) are needed.

An alternative hypothesis could be that Ba residing in the animal's tissues is remobilized by the bivalve during spawning, as was proposed by Gillikin et al. (2006); however, $P$. maximus spawns at the beginning of the spring before the shell $\mathrm{Ba} / \mathrm{Ca}$ peak, as attested by the gonadosomatic index (Fig. 4) (Paulet et al., 1997). It is possible that Ba is used for reproduction and is sequestered to the shell during non-reproductive periods, which would result in low shell $\mathrm{Ba} / \mathrm{Ca}$ during reproduction and high shell $\mathrm{Ba} / \mathrm{Ca}$ during nonreproductive periods as seen here. Preliminary data show that gonads are rich in Ba when compared with muscle tissues (Lorrain, unpublished). The fact that shell $\mathrm{Ba} / \mathrm{Ca}$ peaks exactly when gonad development is at its lowest (Fig. 4) gives support to a Bareproduction link hypothesis. However, it seems unlikely that this would lead to similar variations in shell $\mathrm{Ba} / \mathrm{Ca}$ peak amplitudes between individuals (Fig. 2). This again illustrates the need for further research involving the relationship between ecophysiology and proxy incorporation.

There are other potential causes of the $\mathrm{Ba} / \mathrm{Ca}$ peaks in these shells. For example, if $\mathrm{Ba}$ was to bind to organic matter in the shell, then an enrichment in shell organic matter would result in a high Ba/Ca ratio. However, neither Hart et al. (1997) nor Sinclair (2005) found a relationship between organic matter and Ba concentrations in other biogenic carbonates (i.e., corals), and Rosenthal and Katz (1989) suggest that Ba is bound to the 
crystal phase rather than the organic phase in mollusc shells. Moreover, the slower growing tip of the S. giganteus shells would be expected to have higher organic matter concentrations (Rosenberg et al., 2001), while higher $\mathrm{Ba} / \mathrm{Ca}$ ratios are generally observed in the faster growing back sections of the shells (Fig. 2). Thus it is unlikely that the Ba peaks are associated with shell regions containing higher organic content. There has been one report of barite crystals in bivalve shells, but these shells came from a freshwater environment with extremely high barium concentrations (Fritz et al., 1990), so this is also an unlikely cause of the peaks. Alternatively, the $\mathrm{Ba} / \mathrm{Ca}$ peaks could be a kinetic growth rate effect. Such effects have been noted in both abiogenic calcite and aragonite (Tesoriero and Pankow, 1996; Gaetani and Cohen, 2006), but this is also not supported by our data. The double peak in P. maximus (Fig. 4) cannot be explained in terms of changing growth rates as daily growth rates are fairly constant during peak formation (Fig. 5). Moreover, despite growth slowing from about $18 \mathrm{~mm} / \mathrm{yr}$ in 1993 to about 4 $\mathrm{mm} / \mathrm{yr}$ in 1999 in the S. giganteus shells (See Gillikin et al., 2005a), there are still large $\mathrm{Ba} / \mathrm{Ca}$ peaks in these years (up to $\sim 25 \mu \mathrm{mol} / \mathrm{mol}$; Fig. 2). Therefore, there is no satisfactory variable that can be used to explain these ubiquitous $\mathrm{Ba} / \mathrm{Ca}$ peaks in bivalve shells. Interestingly, Sinclair (2005) also found well synchronized $\mathrm{Ba} / \mathrm{Ca}$ peaks in corals, which could not be correlated to several environmental and biological processes.

\section{Ba Partition coefficients and shell Ba/Ca background}

The partitioning of trace elements $(\mathrm{Me})$ between water and carbonate is typically defined in terms of a partition coefficient: $\mathrm{D}_{\mathrm{Me}}=(\mathrm{Me} / \mathrm{Ca})_{\text {carbonate }} /(\mathrm{Me} / \mathrm{Ca})_{\text {water, }}$, where $\mathrm{Me} / \mathrm{Ca}$ are typically given as molar ratios (see Mucci and Morse 1990). Interestingly, abiogenic calcite and aragonite behave rather differently in regards to $\mathrm{Ba}$ partitioning $\left(\mathrm{D}_{\mathrm{Ba}}\right)$. Typically, abiogenic calcite $\mathrm{D}_{\mathrm{Ba}}$ is precipitation rate dependent and is low, usually $<0.5$ (Mucci and Morse, 1990; Tesoriero and Pankow, 1996). Abiogenic aragonite $\mathrm{D}_{\mathrm{Ba}}$ is strongly temperature dependent and is usually $>0.5$ (Dietzel et al., 2004; Gaetani and Cohen, 2006). However, both the aragonite (S. giganteus) and calcite (P. maximus) shells presented here have similar baseline values (S. giganteus $\sim 1.0$ and P. maximus $\sim 0.7$ $\mu \mathrm{mol} / \mathrm{mol}$ ). Considering a seawater $\mathrm{Ba} / \mathrm{Ca}$ ratio of $3.8 \mu \mathrm{mol} / \mathrm{mol}$ for the Bay of Brest 
(Lorrain, unpublished) and a background $\mathrm{Ba} / \mathrm{Ca}$ ratio of $0.7 \mu \mathrm{mol} / \mathrm{mol}$ for P. maximus, a $\mathrm{D}_{\mathrm{Ba}}$ of 0.18 can be calculated. Similarly, S. giganteus has a $\mathrm{D}_{\mathrm{Ba}}$ of 0.16 using $\mathrm{Ba} / \mathrm{Ca}$ ratios of $1.0 \mu \mathrm{mol} / \mathrm{mol}$ for the shell and $6.2 \mu \mathrm{mol} / \mathrm{mol}$ for the water (Gillikin, 2005). These are both close to the $\mathrm{D}_{\mathrm{Ba}}$ that Gillikin et al. (2006) report for M. edulis ( 0.1). In addition, similar partition coefficients for both mineralogies are evident from the peaks. Aragonite shells had higher peaks in this study, but previous studies presented even higher peaks in calcite shells (e.g., M. edulis up to $70 \mu \mathrm{mol} / \mathrm{mol}$; Vander Putten et al. (2000)). Thus, despite different mineralogies, these species have very similar barium partition coefficients.

While most research has focused on the Ba-peaks, Gillikin et al. (2006) found that the background $\mathrm{Ba} / \mathrm{Ca}$ level in the shells of another bivalve species (Mytilus edulis, calcite shell) could be used as an indicator of dissolved $\mathrm{Ba} / \mathrm{Ca}$ ratios in estuarine water and hence provide an indication of salinity (salinity inversely varies with dissolved $\mathrm{Ba} / \mathrm{Ca}$ ratios in most estuaries). However, in the two S. giganteus shells analyzed here, the background $\mathrm{Ba} / \mathrm{Ca}$ levels are higher near the umbo (Fig. 2). Considering that the $\delta^{18} \mathrm{O}$ data do not suggest a reduced salinity when the clams were younger (see Gillikin et al., $2005 \mathrm{~b}$ ) and the salinity record does not indicate reduced salinities in the Sound, this is probably an ontogenic effect. Unfortunately, this complicates the use of $\mathrm{Ba} / \mathrm{Ca}$ backgrounds in this species, but does highlight the point that species specific differences in elemental incorporation are important and must be taken into consideration. Nevertheless, despite the ontogenic effect, large temporary salinity changes may still be recorded in this species' shells; especially if shell regions of similar age are compared. Considering that the $\mathrm{D}_{\mathrm{Ba}}$ for aragonitic corals (1.27; Lea et al. (1989)) and aragonitic coralline sponges (0.86; Rosenheim et al. (2005)) is much closer to the abiogenic endmember, it can be postulated that these aragonitic bivalves are strongly regulating $\mathrm{Ba}$ incorporation into their shells. This is also evidenced by the fact that Dietzel et al. (2004) report aragonite $\mathrm{D}_{\mathrm{Ba}}$ to be 2.0 at $10{ }^{\circ} \mathrm{C}$ and 1.5 at $25^{\circ} \mathrm{C}$. This temperature dependence in aragonite has also been demonstrated in larval molluscs (Zacherl et al., 2003), coralline sponges (Rosenheim et al., 2005) and corals (Lea et al., 1989), while it is obviously not evident in the shells used in this study (if it were we would expect to see a sinusoidal 
curve in the $S$. giganteus data). Therefore, barium incorporation into bivalve carbonate is not similar to abiogenic carbonate, but does still seems to record some environmental signal.

In conclusion, this study suggests that $\mathrm{Ba} / \mathrm{Ca}$ peaks in bivalve shells are caused by an environmental forcing regardless of mineralogy, albeit with a biological filter. The exact timing between animals growing in the same environment attests to this. Clearly more work is needed to decipher this potential proxy.

\section{Acknowledgements}

We express our gratitude to J. Navez and L. Monin for laboratory assistance. S. Bouillon, A. Verheyden, and M.A. Cunningham gave helpful comments on an earlier version of this manuscript. A. Goewert, B. R. Schöne and D. R. Gröcke (guest editor) provided excellent reviews that greatly improved this manuscript. Funding was provided by the Belgian Federal Science Policy Office (CALMARS I \& II, contracts EV/03/04B \& $\mathrm{SD} / \mathrm{CS} / 02 \mathrm{~A}$ ); and by the Research Foundation Flanders (contract: G.0642.05) and the

European Science Foundation (ESF) under the EUROCORES Programme EuroCLIMATE through contract No. ERAS-CT-2003-980409 (PaleoSalt) of the European Commission, DG Research, FP6.

\section{References}

Bishop JKB (1988) The barite-opal-organic carbon association in oceanic particulate matter. Nature 332:341-343.

Böhm F, Joachimski MM, Dullo WC, Eisenhauer A, Lehnert H, Reitner J, Worheide G (2000) Oxygen isotope fractionation in marine aragonite of coralline sponges. Geochim . Cosmochim Acta 64:1695-1703

Carré M, Bentaleb I, Bruguier O, Ordinola E, Fontugne M (2006) Calcification rate influence on trace elements incorporation in marine bivalve aragonite: evidences and mechanisms. Geochim Cosmochim Acta 70:4906-4920

Chauvaud L, Lorrain A, Dunbar RB, Paulet Y-M, Thouzeau G, Jean F, Guarini J-M, Mucciarone D (2005) The shell of the Great Scallop Pecten maximus as a high frequency archive of paleoenvironmental change. Geochem Geophys Geosys 6, Q08001, doi:10.1029/2004GC000890

Chauvaud L, Thouzeau G, Paulet Y-M (1998) Effects of environmental factors on the daily growth rate of Pecten maximus juveniles in the Bay of Brest (France). J Exp Mar Biol Ecol 227:83-111 
Coffey M, Dehairs F, Collette O, Luther G, Church T, Jickells T (1997) The behaviour of dissolved barium in estuaries. Est Coast Shelf Sci 45:113-121

De Ridder F, Pintelon R, Schoukens J, Gillikin DP, André L, Baeyens W, de Brauwere A, Dehairs F (2004) Decoding nonlinear growth rates in biogenic environmental archives. Geochem Geophys Geosys 5, Q12015, doi:10.1029/2004GC000771

Dehairs F, Chesselet R, Jedwab J (1980) Discrete suspended particles of barite and the barium cycle in the open ocean. Earth Planet Sci Lett 49:528-550

Dietzel MN, Gussone N, Eisenhauer A (2004) Co-precipitation of $\mathrm{Sr}^{2+}$ and $\mathrm{Ba}^{2+}$ with aragonite by membrane diffusion of $\mathrm{CO}_{2}$ between 10 and 50 degrees C. Chem Geol 203:139-151

Freitas PS, Clarke LJ, Kennedy H, Richardson CA Abrantes F (2006) Environmental and biological controls on elemental $(\mathrm{Mg} / \mathrm{Ca}, \mathrm{Sr} / \mathrm{Ca}$ and $\mathrm{Mn} / \mathrm{Ca})$ ratios in shells of the king scallop Pecten maximus. Geochim Cosmochim Acta 70:5119-5133

Fritz LW, Ragone LM, Lutz RA (1990) Biomineralization of barite in the shell of the freshwater Asiatic clam Corbicula fluminea (Mollusca: Bivalvia). Limnol Oceanogr 35:756-762

Gaetani GA, Cohen AL (2006) Element partitioning during precipitation of aragonite from seawater: a framework for understanding paleoproxies. Geochim Cosmochim Acta 70:4617-4634

Ganeshram RS, Francois R, Commeau J, Brown-Leger SL (2003) An experimental investigation of barite formation in seawater. Geochim Cosmochim Acta 67:2599-2605

Gillikin DP (2005) Geochemistry of Marine Bivalve Shells: the potential for paleoenvironmental reconstruction. Ph.D. thesis, Vrije Universiteit Brussel, Belgium, p. 258

Gillikin DP, Dehairs F, Lorrain A, Steenmans D, Baeyens W, André L (2006) Barium uptake into the shells of the common mussel (Mytilus edulis) and the potential for estuarine paleochemistry reconstruction. Geochim Cosmochim Acta 70:395-407

Gillikin DP, De Ridder F, Ulens H, Elskens M, Keppens E, Baeyens W, Dehairs F (2005b) Assessing the reproducibility and reliability of estuarine bivalve shells (Saxidomus giganteus) for sea surface temperature reconstruction: implications for paleoclimate studies. Palaeogeogr Palaeoclimatol Palaeoecol 228:70-85

Gillikin DP, Lorrain A, Navez J, Taylor JW, André L, Keppens E, Baeyens W, Dehairs F (2005a) Strong biological controls on $\mathrm{Sr} / \mathrm{Ca}$ ratios in aragonitic marine bivalve shells. Geochem Geophys Geosys 6, Q05009, doi:10.1029/2004GC000874

Hart SR, Cohen AL, Ramsay P (1997) Microscale analysis of $\mathrm{Sr} / \mathrm{Ca}$ and $\mathrm{Ba} / \mathrm{Ca}$ in Porites. Proceedings of the $8^{\text {th }}$ International Coral Reef Symposium 2:1707-1712

Kingston AW, Gröcke DR, Burchell M (2008) A multiaxial growth analysis of stable isotopes in the modern shell of Saxidomus gigantea: Implications for sclerochronology studies, Geochem Geophys Geosyst 9, Q01007, doi:10.1029/2007GC001807

Lazareth CE, Vander Putten E, André L, Dehairs F (2003) High-resolution trace element profiles in shells of the mangrove bivalve Isognomon ephippium: a record of environmental spatiotemporal variations? Estuarine Coastal Shelf Sci 57:1103-1114

Lea DW (2003) Elemental and isotopic proxies of marine temperatures. In: The Oceans and Marine Geochemistry, Elderfield H (ed.), Oxford: Elsevier-Pergamon, pp. 365-390

Lea DW, Shen GT, Boyle EA (1989) Coralline barium records temporal variability in equatorial Pacific upwelling. Nature 340:373-376

Lorrain A, Gillikin DP, Paulet Y-M, Chauvaud L, Le Mercier A, Navez J, André L (2005) Strong kinetic effects on $\mathrm{Sr} / \mathrm{Ca}$ ratios in the calcitic bivalve Pecten maximus. Geology 33:965-968

Lorrain A, Paulet Y-M, Chauvaud L, Savoye N, Nézan E, Guérin L (2000) Growth anomalies in Pecten maximus from coastal waters (Bay of Brest: France): relationship with diatom blooms. J Mar Biol Ass UK 80:667-673

McCulloch MT, Fallon S, Wyndham T, Hendy E, Lough J, Barnes D (2003) Coral record of increased sediment flux to the inner Great Barrier Reef since European settlement. Nature 421:727-730 
Mucci A, Morse JW (1990) Chemistry of low-temperature abiotic calcites: Experimental studies on coprecipitation, stability and fractionation. Reviews in Aquatic Sciences 3:217-254

Paulet Y-M, Bekhadra F, Dechauvelle N, Donval A, Dorange G (1997) Seasonal cycles, reproduction and oocyte quality in Pecten maximus from the Bay of Brest. Annales de l'Institut océanographique de Paris 73:101-112

Paulet Y-M, Dorange G, Cochard JC, Le Pennec M (1992) Reproduction and recruitment in Pecten maximus L.. Ann Inst Océanogr Paris 681:45-64

Paulet, Y-. M,. and Fifas S. (1989), Potential fecundity of the scallop, Pecten maximus, from the bay of Saint-Brieuc. Haliotis 19:275-285.

Pearce NJG, Perkins WT, Westgate JA, Gorton MP, Jackson SE, Neal CR, Chenery SP (1997) A compilation of new and published major and trace element data for NIST SRM 610 and NIST SRM 612 glass reference materials. Geostand Newsl 21:115-144

Purton LMA, Shields GA, Brasier MD, Grime GW (1999) Metabolism controls Sr/Ca ratios in fossil aragonitic mollusks. Geology 27:1083-1086

Rosenberg GD, Hughes WW, Parker DL, Ray BD (2001) The geometry of bivalve shell chemistry and mantle metabolism. Am Malacol Bull 16:251-261

Rosenheim BE, Swart PK, Thorrold SR (2005) Minor and trace elements in sclerosponge Ceratoporella nicholsoni: Biogenic aragonite near the inorganic endmember? Palaeogeogr Palaeoclimatol Palaeoecol 228:109-129

Rosenthal Y, Katz A (1989) The applicability of trace elements in freshwater shells for paleogeochemical studies. Chem Geol 78:65-76

Sinclair DJ (2005) Non river-flood barium signals in the skeletons of corals from coastal Queensland, Australia. Earth Planet Sci Lett 237:354 - 369.

Sinclair DJ, McCulloch MT (2004) Corals record low mobile barium concentrations in the Burdekin River during the 1974 flood: evidence for limited Ba supply to rivers? Palaeogeogr Palaeoclimat Palaeoecol 214:155-174

Stecher HA, Kogut MB (1999) Rapid barium removal in the Delaware estuary. Geochim Cosmochim Acta, 63:1003-1012

Stecher HA, Krantz DE, Lord CJ, Luther GW, Bock KW (1996) Profiles of strontium and barium in Mercenaria mercenaria and Spisula solidissima shells. Geochim Cosmochim Acta 60:3445-3456

Surge D, Walker KJ (2006) Geochemical variation in microstructural shell layers of the southern quahog (Mercenaria campechiensis): implications for reconstructing seasonality. Palaeogeogr Palaeoclimat Palaeoecol 237:182-190

Takesue RK, van Geen A (2004) Mg/Ca, Sr/Ca, and stable isotopes in modern and Holocene Protothaca staminea shells from a northern California coastal upwelling region. Geochim Cosmochim Acta 68:3845-3861

Tesoriero AJ, Pankow JF (1996) Solid solution partitioning of $\mathrm{Sr}^{2+}, \mathrm{Ba}^{2+}$, and $\mathrm{Cd}^{2+}$ to calcite. Geochim Cosmochim Acta 60:1053-1063

Vander Putten E, Dehairs F, Keppens E, Baeyens W (2000) High resolution distribution of trace elements in the calcite shell layer of modern Mytilus edulis: Environmental and biological controls. Geochim Cosmochim Acta 64:997-1011

Walter E, Pronzato L (1994) Identification de Modèles Paramétriques à Partir de Données Expérimentales, Masson, Paris 371 pp

Zacherl DC, Paradis G, Lea DW (2003) Barium and strontium uptake into larval protoconchs and statoliths of the marine neogastropod Kelletia kelledi. Geochim Cosmochim Acta 67:40914099 


\section{$\underline{\text { Figure legends }}$}

Figure 1. Pictures of the bivalve species used in this study: Saxidomus giganteus (1a; scale bar $=1 \mathrm{~cm})$ and Pecten maximus $(1 \mathrm{~b}$; scale bar $=1 \mathrm{~cm})$. A detail of the daily striae on $P$. maximus shells are also shown $(1 \mathrm{c} ;$ scale bar $=1 \mathrm{~mm})$.

Figure 2. Ba/Ca ratios in two Saxidomus giganteus shells that grew side by side in Puget Sound (solid and open circles). The solid green line is chlorophyll $a$ and the dotted line is water temperature. Arrows indicate the synchronous sharp peaks noted in the text and red circle highlights the mis-matched section of the profile. Note that each year mark denotes the first day of that year. One Chl $a$ peak extends beyond the chart axis (labeled as 35.4 $\mu \mathrm{g} / \mathrm{L})$.

[Note to production editor: This Figure (Figure 2) should be as large as possible to show all features of the figure. Please set it to be as wide as the page width.

Figure 3. An enlargement of two sections of the Saxidomus giganteus data presented in Figure 2. The left panel (a) shows the first three large $\mathrm{Ba} / \mathrm{Ca}$ peaks which correlate very well between the two shells and the right panel (b) shows the section of shell with the poorest match between the two shells. The difference in background levels though ontogeny is also more visible in these panels (i.e., they are higher in the right panel).

Figure 4. $\mathrm{Ba} / \mathrm{Ca}$ ratios in three age class I (open symbols) and one age class II (crosses) Pecten maximus shells that grew in the Bay of Brest (France). The solid green line is chlorophyll $a$ and the dashed grey line is water temperature. The dashed black line and solid black symbols are the gonad index (dry weight of the gonad divided by the shell weight (x1000)). Note that each month mark denotes the first day of that month.

Figure 5. Daily shell growth rates in three age class I (solid lines) and one age class II (dashed line) Pecten maximus shells that grew in the Bay of Brest (France). The solid 
green line is chlorophyll $a$. The red circles highlight the growth minima during the growth dip. Note that each month mark denotes the first day of that month. 


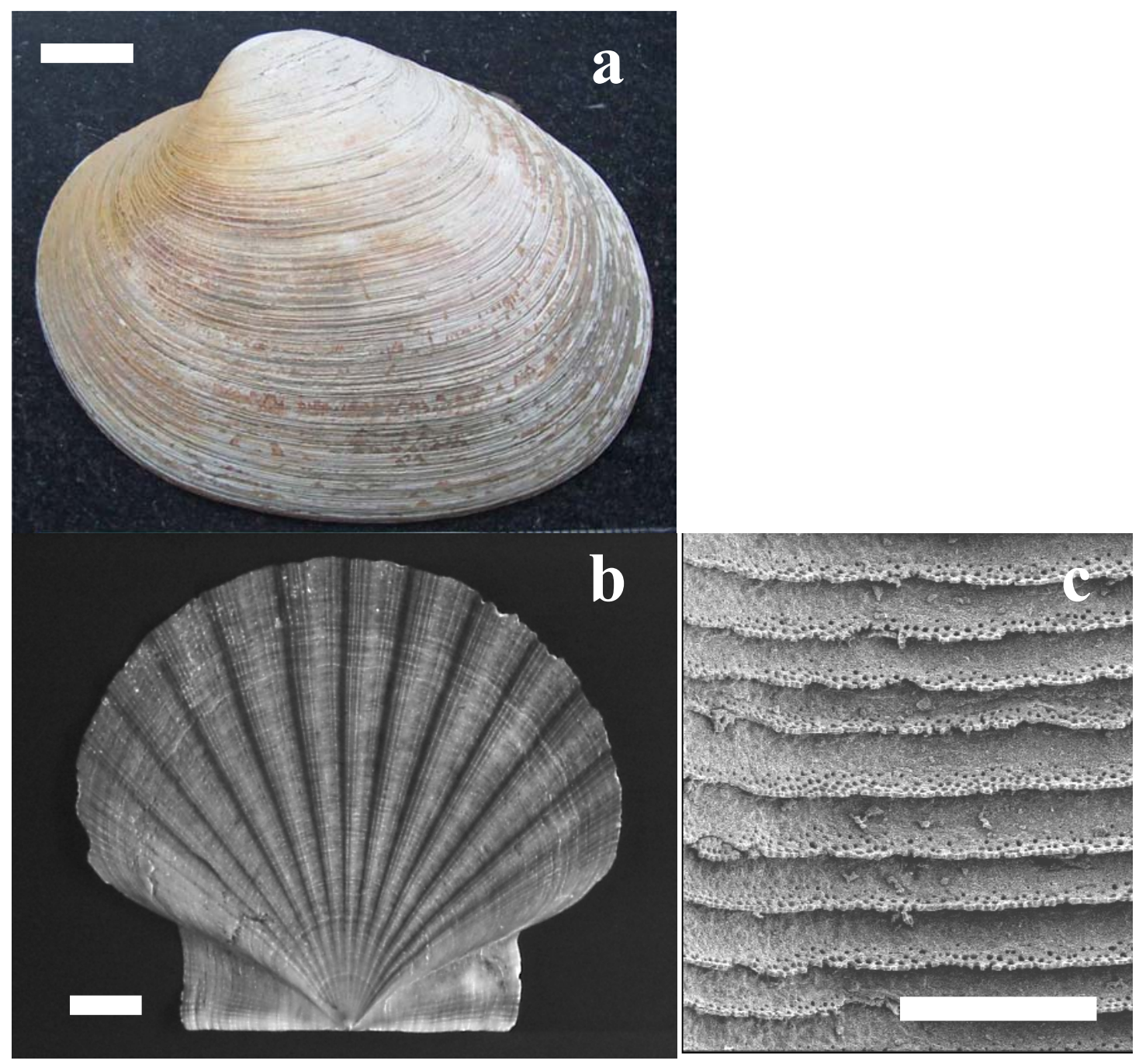

Figure 1. Pictures of the bivalve species used in this study: Saxidomus giganteus (1a; scale bar $=1 \mathrm{~cm})$ and Pecten maximus $(1 \mathrm{~b}$; scale bar $=1 \mathrm{~cm})$. A detail of the daily striae on $P$. maximus shells are also shown (1c; scale bar $=1 \mathrm{~mm})$. 


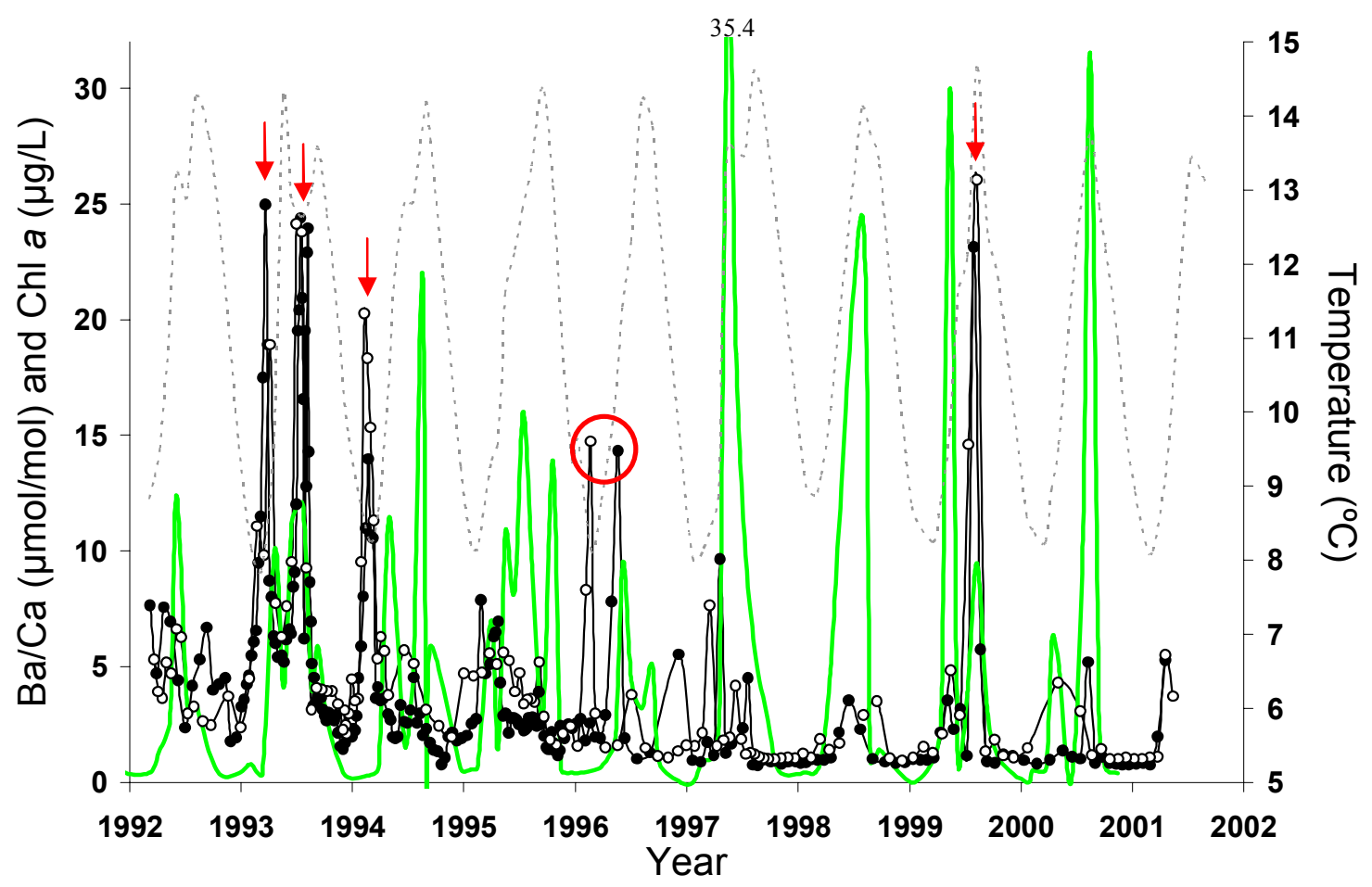

Figure 2. $\mathrm{Ba} / \mathrm{Ca}$ ratios in two Saxidomus giganteus shells that grew side by side in Puget Sound (solid and open circles). The solid green line is chlorophyll $a$ and the dotted line is water temperature. Arrows indicate the synchronous sharp peaks noted in the text and red circle highlights the mis-matched section of the profile (see also Fig. 3). Note that each year mark denotes the first day of that year. One $\mathrm{Chl} a$ peak extends beyond the chart axis (labeled as $35.4 \mu \mathrm{g} / \mathrm{L}$ ). 

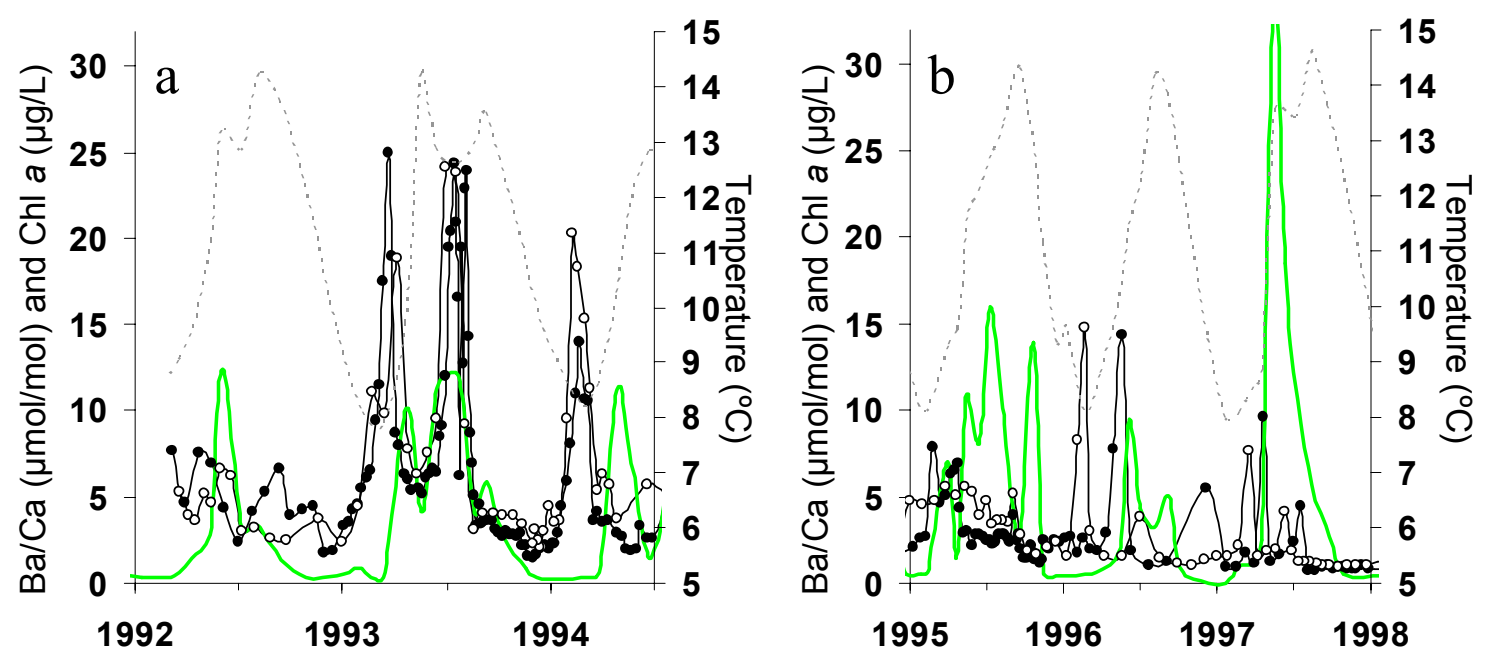

Figure 3. An enlargement of two sections of the Saxidomus giganteus data presented in Figure 2. The left panel (a) shows the first three large $\mathrm{Ba} / \mathrm{Ca}$ peaks which correlate very well between the two shells and the right panel (b) shows the section of shell with the poorest match between the two shells. The difference in background levels though ontogeny is also more visible in these panels (i.e., they are higher in the right panel). 


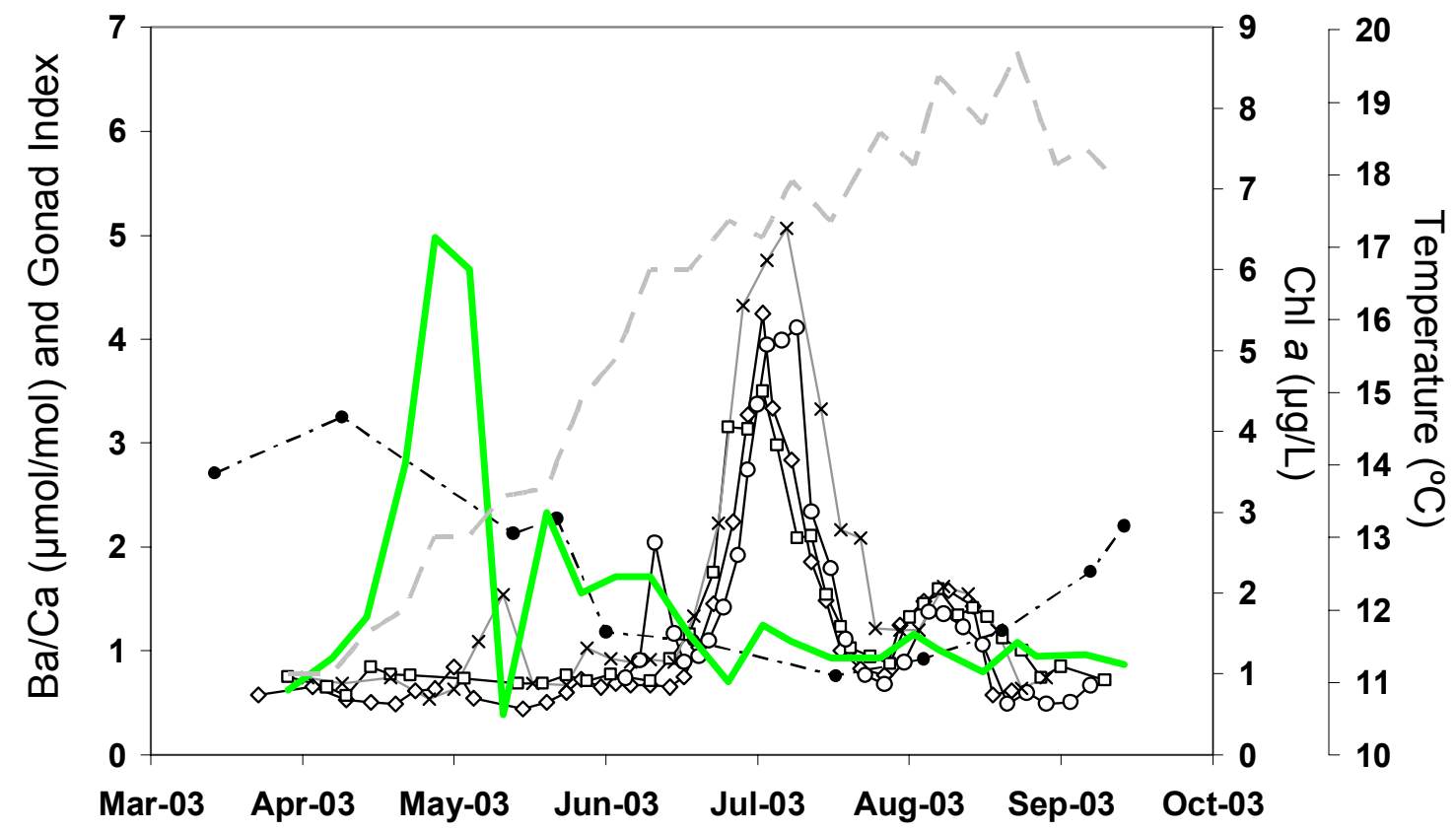

Figure 4. $\mathrm{Ba} / \mathrm{Ca}$ ratios in three age class I (open symbols) and one age class II (crosses) Pecten maximus shells that grew in the Bay of Brest (France). The solid green line is chlorophyll $a$ and the dashed grey line is water temperature. The dashed black line and solid black symbols are the gonad index (dry weight of the gonad divided by the shell weight (x1000)). Note that each month mark denotes the first day of that month. 


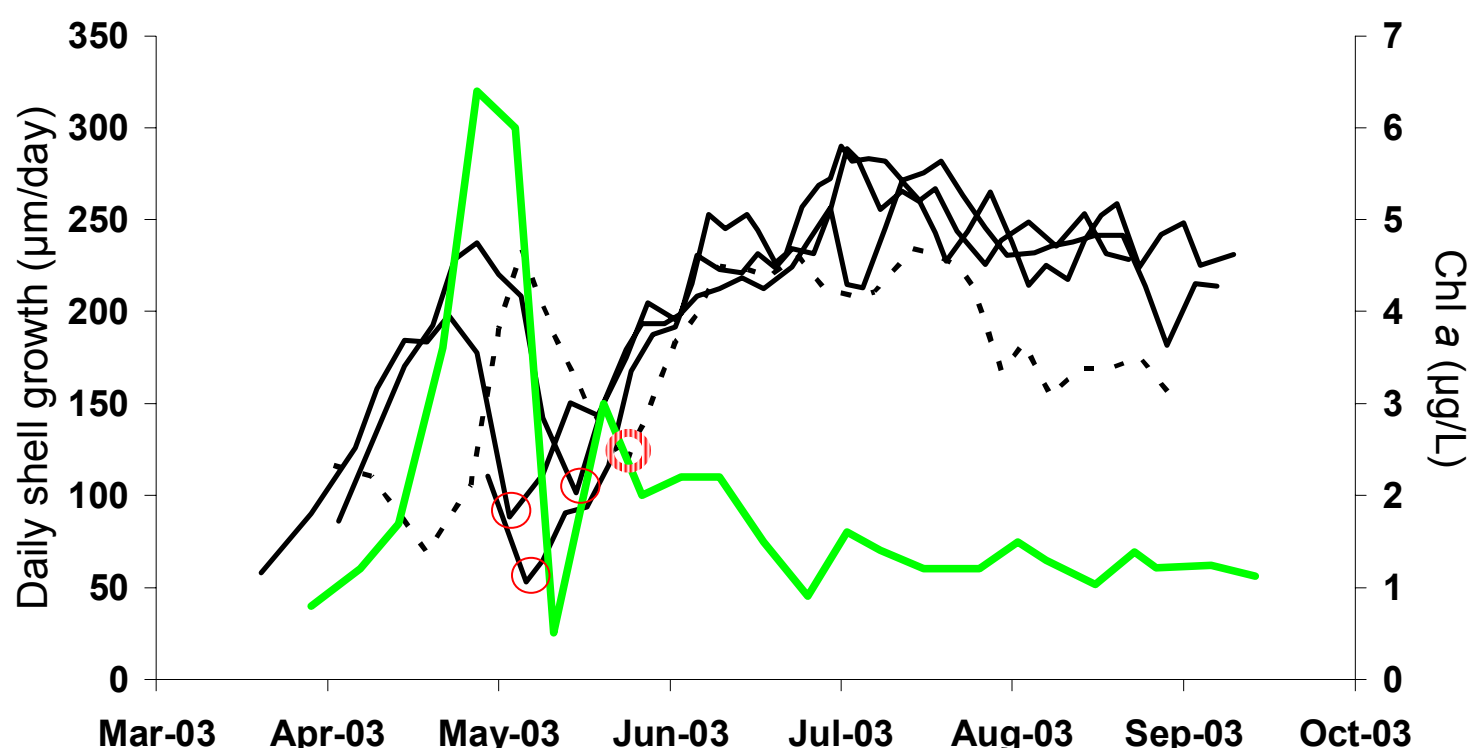

Figure 5. Daily shell growth rates in three age class I (solid lines) and one age class II (dashed line) Pecten maximus shells that grew in the Bay of Brest (France). The solid green line is chlorophyll $a$. The red circles highlight the growth minima during the growth dip. Note that each month mark denotes the first day of that month. 